\title{
JOURNAL.RU
}

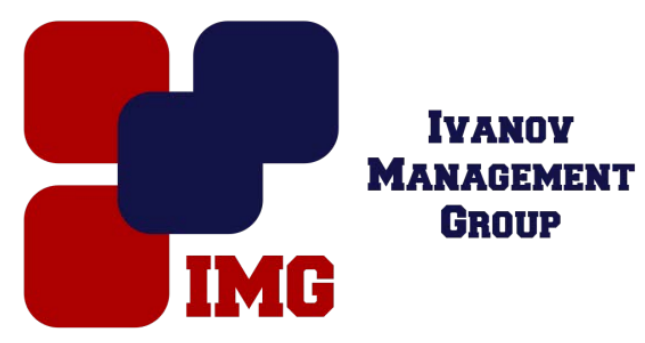

Фахрутдинова Р.А., Васильева И.Д. ФГАОУ ВПО Казанский (Приволжский) Федеральный Университет, Институт филологии и межкультурной коммуникации, кафедра образовательных технологий и информачионных систем в филологии Казань, Россия

doi: 10.18411/lj-30-11-2016-1-12

idsp 000001:lj-30-11-2016-1-12

\section{Развитие организаторских способностей студентов СПО средствами интерактивных технологий обучения}

\section{Аннотация}

В современных условиях модернизации образования подготовка специалистов ориентирована не на передачу готовых знаний, а на формирование компетенций, включающих в себя различные способности. Авторами рассматриваются интерактивные технологии обучения, направленные на развитие организаторских способностей студентов СПО при изучении иностранного языка.

Ключевые слова: организаторские способности, интерактивные технологии обучения, студенты СПО, иностранный язык

В соответствии с требованиями ФГОС СПО к результатам освоения программы подготовки специалистов среднего звена,педагог по адаптивной физической культуре должен обладать общими и профессиональными компетенциями, включающие в себя различные способности. Организаторским способностям в стандарте уделяется большое внимание, а именно будущий специалист должен:

- организовывать физкультурно-спортивную деятельность лиц с ограниченными возможностями здоровья;

- организовывать и проводить учебно-тренировочные занятия, руководить соревновательной деятельностью спортсменов в избранном виде адаптивного спорта;

- организовывать обустройство и эксплуатацию спортивных сооружений и мест занятий физической культурой и спортом и т.д.

Исходя из вышеизложенного, становится очевидной актуальность выработки комплекса мер по развитию организаторских способностей студентов, так как они являются организаторами учебно-воспитательного процесса и воспитателями всесторонне развитого поколения.

Проблема способностей многогранна и многоаспектна, поэтому представляет сложность для исследователей. На сегодняшний день существуют 
различные подходы к определению способностей, в словарях «способности» определяются как индивидуально-психологические особенности личности, являющиеся субъективными условиями успешного осуществления определенного рода деятельности.

Способности выявляются в процессе освоения человеком какой-либо деятельности и проявляются в том, какон быстро и основательно, легко и прочно присваивает способы ее организации и осуществления.

Среди способностей особое место занимают организаторские, которые включают расположенность человека к коммуникации, развитость практического склада ума, инициативность, умение активизировать других в различных ситуациях, критичность, требовательность к себе и другим, готовность к принятию решений и стимулированию к этому окружающих [2, с. 292].

В психолого-педагогической литературе понятие «организаторские способности» рассматривается как индивидуально-психологические особенности личности, являющиеся условиями успешного овладения организаторской деятельностью и ее осуществления [3, с. 86].

Так же организаторские способности связывают с успешным овладением организаторской деятельностью, с умением эффективно выстраивать межличностное общение и взаимодействие, воздействовать на личность и коллектив в образовательной сфере, тем самым побуждать к самовоспитанию, самообразованию и саморазвитию.

На наш взгляд, наиболее эффективным средством развития организаторских способностей является интерактивные технологии обучения, которые позволяют студентамвключаться в практическую деятельность, где они выступают в роли организаторов и упражняются в приобретении знаний и умений.

На уроках иностранного языка авторами успешно применялись технологии интерактивного обучения при ведении нового материала, его закреплении, при решении педагогических задач. На занятиях использовалась групповая форма работы, где студенты имеют возможность высказать свое мнение, обменяться идеями с напарниками, они самостоятельно устанавливают взаимодействие друг с другом, организуют работу, распределяют обязанности, выбирают средства и способы достижения поставленной цели.

В рамках закрепления лексического материала по теме «Sportcompetitions» студентам было предложено составить кроссворды в мини группах. Задача студентов заключалось в том, чтобы организовать работу каждого члена группы так, чтобы за ограниченное количество времени использовать как можно больше лексических единиц.

В процессе выполнения данного задания активизировался творческий потенциал каждого участника, студенты обменивались идеями, знаниями. Результаты совместной групповой работыбезусловно превышаютрезультаты отдельных студентов.

В рамках темы «Sportevents» будущим педагогам по адаптивной физической культуребыло предложеновыступить в качестве организаторов спортивного мероприятия и составить его план.Студентам нужно было обозначить цели, задачи, предусмотреть место и время проведения мероприятия, подготовить нужный инвентарь, продумать ход мероприятия и т.д.

Подобные заданияформируют личность организатора в процессе предоставления решения организаторских задач, организации общественно 
полезной деятельности.

Таким образом, внедрениеинтерактивных технологийв учебный процесс дает студентам возможность реализовать себя,проявить способности, взаимодействовать сколлективом и влиять на результатыработы. Bce этобезусловноположительно влияет наразвитие организаторских способностейстудентов СПО. 


\section{Литература}

1. Кузнецова, В. С. Формирование организаторскихумений у студентов педагогических вузов / В. С. Кузнецова. - М., 1976.

2. Словарь по социальной педагогике / авт.-сост. JІ.В. Мардахаев. - М.: Изд. Центр «Академия», 2002. - 368 с.

3. Уманский Л.И. Психология организаторской деятельности школьника.М.:Просвещение, 1980. - 126 с.

4. У Упавление самостоятельной работой студентов: метод.пособие / под общ. ред. И.П. Пастуховой. М.: Б-ка ж-ла «СПО», 2006. 